\title{
Revised and updated vascular plant checklists for the Baja California Northern Pacific Islands
}

\author{
Sula Vanderplank ${ }^{1,2, *}$, Jon Rebman ${ }^{3}$, and Exequiel Ezcurra ${ }^{4}$ \\ ${ }^{1}$ Centro de Investigación Científica y de Educación Superior de Ensenada, \\ Carretera Ensenada - Tijuana \#3918, 22860 Ensenada, B.C., México \\ ${ }^{2}$ Botanical Research Institute of Texas, 1700 University Drive, Fort Worth, TX 76107 \\ ${ }^{3}$ San Diego Natural History Museum, Box 121390, San Diego, CA 92112 \\ ${ }^{4}$ University of California Institute for Mexico and the United States (UCMEXUS), \\ 900 University Ave, Riverside, CA 92521
}

\begin{abstract}
In the last 3 years, significant advances have occurred in our knowledge of the flora of the northern Baja California Pacific Islands. The availability of herbarium specimen data has been significantly increased, and 2 expeditions were undertaken to 7 of the 8 islands in 2015 and 2016. These events have resulted in a wealth of new plant records from the islands, which are here reported with updated taxonomy for the archipelago. The results include 586 vascular plant taxa on the Baja California Northern Pacific Islands; 118 taxa were new, and 54 previously reported taxa were vouchered. The checklists include the nativity of the taxa and highlight new records discovered through fieldwork, as well as those that were hidden in herbaria until now. The declaration of these islands as a new UNESCO Biosphere Reserve in late 2016 makes these new records of particular conservation importance, bettering our baseline understanding of these islands' ecosystems.

RESUMEN.-En los últimos tres años, han ocurrido importantes avances en nuestro conocimiento sobre la flora de las Islas del Pacífico de Baja California. La información disponible de especímenes de herbarios ha incrementado significativamente, además de, dos expediciones que se llevaron a cabo en siete de las ocho islas en 2015 y 2016 . Estos sucesos dieron lugar al enriquecimiento de nuevos registros de plantas de las islas, los cuales son reportados aquí, junto a la taxonomía actualizada del archipiélago. Los resultados incluyen 586 taxones de plantas vasculares de las Islas del Pacifico de Baja California Norte, incluyendo 118 nuevos taxones y 54 taxones adicionales que están siendo verificados. Las listas comprenden la procedencia de los taxones, destacando nuevos registros descubiertos a partir de trabajo de campo, así como aquellos taxones que, hasta la fecha, habían permanecido ocultos en herbarios. La declaración de estas islas como una nueva Reserva de la Biosfera a fines de 2016, hizo a estos nuevos registros de particular importancia en la conservación, mejorando nuestro entendimiento de los ecosistemas de estas islas.
\end{abstract}

The Baja California Northern Pacific Islands consist of 8 island complexes: Coronado, Todos Santos, San Martín, San Jerónimo, Guadalupe, San Benito, Cedros, and Natividad. Seven of these island complexes (all but Guadalupe Island) are nearshore continental shelf or land-bridge islands, which were previously connected to the mainland. (Note: San Roque, Asunción, Santa Margarita, and Magdalena Islands [Baja California Sur] are sometimes included in this archipelago but are not addressed in this paper.) These islands are of particular interest to biologists for many reasons, including (1) their significant recovery after the removal of nonnative species (e.g., Tershy et al. 1997, Garcillán et al. 2008, Aguirre-
Muñoz et al. 2008, 2011, Rodríguez-Malagón et al. 2010); (2) the presence of many endemic species (e.g., Mellink 1992, Vanderplank and Mata 2010), with endemic island faunal taxa including 15 reptiles, 8 birds, and 11 mammals (Vanderplank et al. 2017); and (3) their proximity to the California Channel Islands and shared island floras (e.g., Ratay et al. 2014).

Biological research on the Baja California Pacific Islands began in the 1800s with visitors such as Thomas Streets (1875), soon followed by Charles Pond, Edward Palmer (1888-1889), Alfred Anthony, and Townshend Brandegee (1900), all of whom collected specimens. Since then, a series of botanists have made significant collections on the islands including Reid

*Corresponding author: sula.vanderplank@gmail.com 
Moran, Steve Junak, Ralph Philbrick, Michael Benedict, and Jon Rebman. Junak and Philbrick published several island floras (Junak and Philbrick 1994a, 1994b, 2002a, 2002b), and Tom Oberbauer published on the floras of Coronado and Cedros (Oberbauer 1987, 2002a, $2002 \mathrm{~b}$ ). Jon Rebman and others updated the vascular plant checklist for Guadalupe Island (Rebman 2006, Rebman et al. 2007). In 1985 a compilation of the vascular plant floras of the California and Baja California Islands was published (Wallace 1985), and most recently, in 2014, Ratay et al. updated and revised the checklists and their taxonomy for the Channel Islands and Baja California Islands, including many new records, but without extensive fieldwork or herbarium searches.

In December 2016, the Mexican government declared these islands part of a new Natural Protected Area for the Pacific Islands of Baja California (which included Adelaida, Los Alijos, and Bahía Magdalena). To assist in the renewed conservation efforts on these magnificent microcosms, we hereby present updated plant checklists for each island, including notes on nativity and endemism.

Many historical specimens have been buried in regional herbaria, but in 2014 the Consortium of California Herbaria received a supplemental grant from the National Science Foundation to the funded collaborative proposal "Harnessing the power of herbaria to understand the changing flora of California: a biodiversity hotspot in peril." The funding allowed digitization of more than 20,000 herbarium specimens from northwestern Baja California, held at 4 herbaria in the USA (Rancho Santa Ana Botanic Garden and Pomona College herbarium [RSA-POM], Santa Barbara Botanic Garden herbarium [SBBG], California Academy of Sciences and the Dudley Herbarium [CAS-DS], and the University of California and Jepson Herbaria [UC-JEPS]), including specimens from the Baja California Pacific Islands. This wealth of new data has improved our knowledge of the island floras, and to update the available field data on the floras of these islands, 2 major botanical expeditions were taken to the land-bridge islands in 2015 and 2016.

\section{MeTHODS}

The checklist of Ratay et al. (2014) was used as a starting point, and 2 expeditions
(2015 and 2016) were undertaken to record and document new species and collect reported taxa that lacked voucher specimens. Researchers spread out in a targeted search for new plant occurrences on the land-bridge islands. New occurrences are vouchered and in process of accession at the herbaria of the Autonomous University of Baja California in Ensenada (BCMEX), the San Diego Natural History Museum (SD), and the Botanical Research Institute of Texas (BRIT). For the flora of Guadalupe Island, new records are minimal, because an intensive botanical collecting expedition has not been conducted since 2010. The known flora is included here for comparative purposes, although it should be noted that there may be additional new records on Guadalupe Island to which the authors did not have access.

Herbarium searches revealed numerous new taxa for Cedros Island in particular, and visits by the authors to the RSA, CAS, UC, and SBBG herbaria were particularly helpful in the identification of new herbarium voucher specimens. Taxonomy follows Rebman et al. (2016), which is an annotated plant checklist for the Baja California region. Ambiguous infraspecific taxa have been removed, and many plants previously known only in the literature have had voucher specimens added.

\section{Results and Discussion}

In total, the islands are home to 586 plants including 492 native taxa and 94 nonnative taxa (Appendix 1). Hybrid taxa are included as species in the calculations that follow.

When the total species richness of the islands was plotted against the island total area, we found that the species-area relationship had a slope of 0.3 on a log-log scale, as predicted by McArthur and Wilson's classical model of island biogeography (MacArthur and Wilson 1967). However, we also found that some islands differed significantly from the model predictions (Fig. 1). San Jerónimo and, to a lesser degree, Guadalupe are depauperate islands with significantly lower species richness than predicted by the model, while Coronado, Todos Santos, and, to a lesser degree, San Martín, are significantly speciose islands with a significantly higher richness than predicted by the model.

The northern Baja California Pacific Islands remain an area of particular interest 

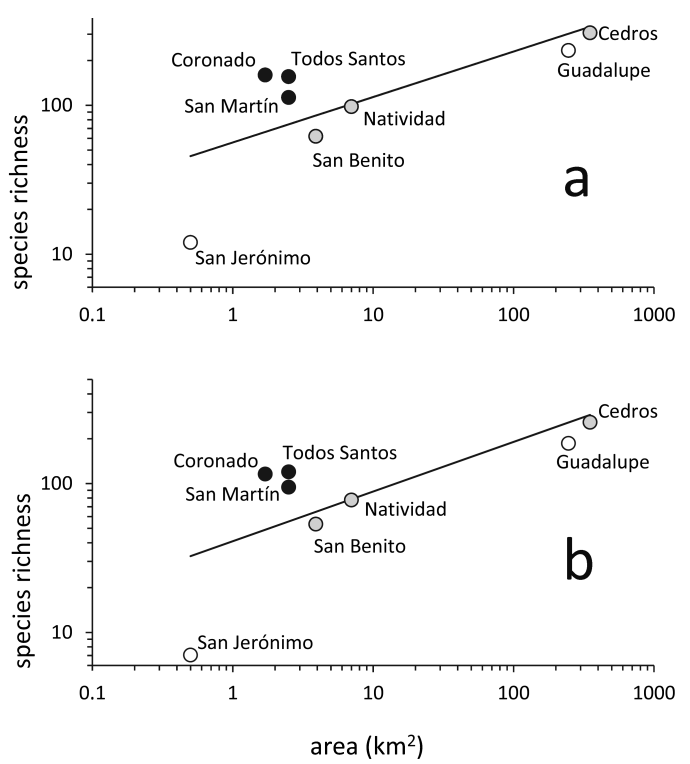

Fig. 1. Species-area relationship for the Baja California Northern Pacific Islands, plotted on a log-log scale: (a) total flora and (b) natives only. The regression lines show the predictions of the MacArthur and Wilson (1967) model. In both data sets the results are similar: islands marked by white symbols (San Jerónimo and Guadalupe) are significantly depauperate for their areas (i.e., they lie significantly below the model line according to a Poisson distribution model). Islands marked by black symbols (Coronado, Todos Santos, and San Martín) are significantly speciose for their areas.

for floristicians, with new records continuing to be found. The expeditions of 2015 and 2016, combined with historical specimen searches, revealed a total of 53 new plant taxa in the known flora of the Baja California Pacific Island Archipelago. The addition of 118 new records on individual islands is a significant improvement in our knowledge of the flora, and the vouchering of 54 additional taxa confirms early reports of these floristic elements. The availability of these 172 total vouchered taxa in regional herbaria will better our understanding of the islands and improve taxonomic study of the island populations.

The highest numbers of total vascular plant taxa (and native plant taxa) are found on the largest 2 islands, Cedros and Guadalupe, respectively (Table 1). A significantly high number of new records were added to Cedros, perhaps due to its sheer size and general inaccessibility. The high numbers of new taxa from the Coronado Islands and Natividad reflect the additional access challenges and lack of botanical visitation in recent years.

The total species richness by area is highest in the northern islands, which receive considerably more rainfall than the southern islands, particularly in El Niño years (Caso et al. 2007). The percentage of nonnative taxa shows a similar decline, with the anomaly of San Jerónimo Island, which exhibits the highest percentage of nonnative plants-almost half of its small flora (5 of 12 taxa). The San Benito Islands currently have the lowest recorded numbers of nonnative plants (14\%), perhaps in part due to their southerly position and aridity. Although Natividad has a higher percentage of nonnatives $(21 \%)$, the majority are at this time restricted to the village. The percentage of nonnative plant taxa on the islands (16\%) is higher than that of the adjacent peninsula (10.9\%; Rebman et al. 2016). As summarized in Table 2, the highest numbers of endemic plants are found on the oceanic island of Guadalupe, which has more single-island endemics (Table 1) than all the other islands combined and displays the highest endemic density at $9.6 / \mathrm{km}^{2}$. The small island complexes of San Benito and Coronado have endemic densities of $6.0 / \mathrm{km}^{2}$ and $5.1 / \mathrm{km}^{2}$, respectively. Fig. 1 shows that San Jerónimo and Guadalupe Island have significantly more depauperate native and total floras. On Guadalupe, the depauperate flora is likely a result of the distance from the mainland, the severe history of nonnative grazers, and a lack of intensive floristic study in recent years of recuperation. On San Jerónimo, it likely results from heavy guano deposits and the history of guano extraction. The 3 northernmost islands (Coronado, Todos Santos, and San Martín) show higher floristic diversity, which is probably a result of higher mean annual rainfall and proximity to the coast (and prior connection to the coast for Coronado and Todos Santos).

At a time when the islands are receiving increased protection and management, it is particularly important to have a strong baseline of floristic knowledge. Conservation continues to be challenging on these islands (Mellink 1993), and a wealth of rare and endemic species from northwestern Baja California are found on these islands (Rebman et al. 2016, O'Brien et al. in press). Advances in data sharing and informatics (e.g., the Baja California Botanical Consortium and the 
TABLE 1. The northern Baja California Pacific Islands (from north to south), island size, distance from adjacent mainland (if the island is closest to another island, the interisland distance is noted in parentheses), total number of plant taxa, plant taxa added to the islands in this publication (number in parentheses represents the taxa previously reported for which vouchers were located), nonnative plant taxa, plant taxa endemic to just that one island, and insular endemic taxa present. Note that the combined island values for total taxa and nonnative taxa are not cumulative because some taxa occur on multiple islands.

\begin{tabular}{lccccccc}
\hline Island & $\begin{array}{c}\text { Size } \\
\left(\mathrm{km}^{2}\right)\end{array}$ & $\begin{array}{c}\text { Distance } \\
\text { from land } \\
(\mathrm{km})\end{array}$ & Total taxa & $\begin{array}{c}\text { New } \\
\text { taxa added } \\
\text { (vouchers) }\end{array}$ & Nonnatives & $\begin{array}{c}\text { Island } \\
\text { endemics }\end{array}$ & $\begin{array}{c}\text { Single } \\
\text { island } \\
\text { endemics }\end{array}$ \\
\hline Coronado & 1.7 & 13.5 & 160 & $29(4)$ & 45 & 6 & 3 \\
Todos Santos & 2.5 & 6.25 & 156 & $11(1)$ & 37 & 1 & 0 \\
San Martín & 2.5 & 5 & 113 & $7(1)$ & 19 & 3 & 1 \\
San Jerónimo & 0.5 & 9 & 12 & $6(0)$ & 5 & 1 & 0 \\
Guadalupe & 246 & 157 & 234 & $3(2)$ & 49 & 50 & $38+$ \\
San Benito & 3.9 & $67(28)$ & 62 & $4(7)$ & 9 & 9 & 3 \\
Cedros & 350 & $12(16)$ & 307 & $37(41)$ & 51 & 21 & 15 \\
Natividad & 7 & 6 & 98 & $18(1)$ & 21 & 4 & 1 \\
ALL ISLANDS & 614 & & {$[586]$} & $115(57)$ & {$[94]$} & 83 & $60+$ \\
\hline
\end{tabular}

TABLE 2. Numbers of total, native, and endemic taxa per square kilometer $\left(\mathrm{km}^{2}\right)$, and percentages of native taxa on each island. Because of the nonlinear relationship between species richness and island area, the floristic density of each island was standardized to an area of $1 \mathrm{~km}^{2}$ using MacArthur and Wilson's (1967) species area model: floristic density $=\mathrm{S} / \mathrm{A}^{0.3}$.

\begin{tabular}{lcccc}
\hline & & \multicolumn{3}{c}{ Floristic density $\left(\mathrm{species} / \mathrm{km}^{2}\right)$} \\
\cline { 3 - 5 } Island & Natives $(\%)$ & Total taxa & Natives & Endemics \\
\hline Coronado & 71.9 & 136.5 & 98.1 & 5.1 \\
Todos Santos & 76.3 & 118.5 & 90.4 & 0.8 \\
San Martín & 83.2 & 85.8 & 71.4 & 2.3 \\
San Jerónimo & 58.3 & 44.8 & 8.6 & 1.2 \\
Guadalupe & 79.1 & 41.2 & 35.5 & 9.6 \\
San Benito & 85.5 & 53.0 & 44.2 & 6.0 \\
Cedros & 83.4 & 54.7 & 42.9 & 3.6 \\
Natividad & 78.6 & 85.4 & 71.7 & 2.2 \\
ALL ISLANDS & 84.0 & & 12.1 \\
\hline
\end{tabular}

Consortium of California Herbaria, which now includes records from the California Floristic Province) have significantly furthered our knowledge of the island floras. Regular botanical exploration of the islands is necessary to understand changes in the island floras, search for new occurrences of plant taxa (both native and nonnative) in different years, and monitor the long-term recovery of island ecosystems following the eradication of nonnative mammals.

\section{Conclusion}

With increased study, our knowledge of the flora of the Baja California Pacific Islands continues to increase. In this study new records were added to each of the land-bridge islands, with the greatest number coming from the northernmost and southernmost islands and appearing to be mostly dictated by ease of access. The percentage of nonnative species is comparatively higher than the regional average on all islands. Total floristic diversity and endemism are highest on the largest islands, with the oceanic island of Guadalupe being home to the greatest endemism. Continued study of these islands will doubtlessly reveal additional taxa, inform conservation efforts, and assist management efforts in the newly created biosphere reserve.

\section{ACKNOWLEDGMENTS}

Many people assisted with the island fieldwork in 2015 and 2016, and we are especially grateful to Steve Junak, Tom Oberbauer, Shannon Still, Andy Pignolo, Vince Scheidt, Bart O'Brien, Mike and Ellen Uhler, Ken Niessen, Tom Mulroy, Steve McCabe, Chris Mankey, Katherine McEachern, Sarah Chaney, Dan Richards, Carlos A. De La Rosa, Anny 
Peralta, Alan Harper, Carly Taft, Michael Benedict, Matt Guilliams, Denise and John Knapp, and Steve Windhager. We thank the Jiji Foundation for funding 3 of the 2015 expedition participants. All specimens were collected under permits graciously issued by SEMARNAT. We thank collections managers Layla Aerne Hains (SD), Mare Nazaire (RSAPOM), Rebecca Peters (CAS), Andrew Doran (UC), and Adrie Hernandez (SBBG) for assistance with access to historical specimens. We additionally thank Matt Guilliams for confirming the identification of specimens at SBBG. We thank Jose Luis Villalobos Guzmán of the Port Captains office and Aneth Yovana Sanchez Talamantes for their hospitality on Cedros Island. We thank Jorge Torre of Comunidad y Biodiversidad and Arturo Hernández Velasco, Abraham Mayoral, and Antonio Espinoza of the Cooperativa Buzos y Pescadores de la Baja California for their hospitality on Natividad Island.

\section{Literature Cited}

Aguirre-Muñoz, A., D.A. Croll, J. Donlan, R.W. Henry III, M.A. Hermosillo, G.R. Howald, B.S. KeitT, L. Luna-Mendoza, M. Rodríguez-Malagón, L.M. SAlas-Flores, ET AL. 2008. High-impact conservation: invasive mammal eradications from the islands of western Mexico. AMBIO: A Journal of the Human Environment 37(2):101-107.

Aguirre-Munoz, A., A. Samaniego-Herrera, L. LunaMendoza, A. Ortiz-Alcaraz, M. Rodríguez-MaLagón, M. Méndez-Sánchez, M. FÉlix-LizÁrraga, J.C. Hernández-Montoya, R. GonZÁLEZ-Gómez, F. Torres-García, ET AL. 2011. Island restoration in Mexico: ecological outcomes after systematic eradications of invasive mammals. Pages 250-258 in C.R. Veitch, M.N. Clout, and D.R. Towns, editors, Island invasives: eradication and management. Proceedings of the International Conference on Island Invasives. Occasional Paper of the IUCN Species Survival Commission No. 42.

Caso, M., C. González-Abraham, and E. Ezcurra. 2007. Divergent ecological effects of oceanographic anomalies on terrestrial ecosystems of the Mexican Pacific Coast. Proceedings of the National Academy of Sciences 104:10530-10535

Garcillán, P., E. Ezcurra, and E. Vega. 2008. Guadalupe Island: lost paradise recovered? Overgrazing impact on extinction in a remote oceanic island as estimated through accumulation functions. Biodiversity and Conservation 17:1613-1625.

JunAK, S., AND R. PhiLbRick. 1994a. The flowering plants of San Martin Island, Baja California, Mexico. Pages 429-447 in W. Halvorsen and G. Maender, editors, Proceedings of the Fourth California Islands Symposium: update on the state of resources. Santa Barbara Museum of Natural History, Santa Barbara, CA.
Junak, S., AND R. Philbrick. 1994b. The vascular plants of Todos Santos Island, Baja California, Mexico. Pages 407-428 in W. Halvorson and G. Maender, editors, Proceedings of the Fourth California Islands Symposium: update on the state of resources. Santa Barbara Museum of Natural History, Santa Barbara, CA.

Junak, S., AND R. Philbrick. 2002a. Flowering plants of Natividad Island, Baja California, México. Pages 224-234 in H.W. Chaney, K.L. Mitchel, and D.R. Browne, editors, Proceedings of the Fifth California Islands Symposium. Santa Barbara Museum of Natural History, Santa Barbara, CA.

Junak, S., AND R. Philbrick. 2002b. Flowering plants of the San Benito Islands, Baja California, Mexico. Pages 235-246 in H.W. Chaney, K.L. Mitchel, and D.R. Browne, editors, Proceedings of the Fifth California Islands Symposium, Santa Barbara Museum of Natural History, Santa Barbara, CA.

MacArThur, R.H., And E.O. Wilson. 1967. Theory of island biogeography. Princeton University Press, Princeton, NJ.

MELLinK, E. 1992. Status de los heterómidos y cricétidos endémicos del estado de Baja California. Comunicaciones Académicas, Serie Ecología. Centro de Investigación Científica y de Educación Superior de Ensenada, Ensenada, México.

Mellink, E. 1993. Biological conservation of Isla de Cedros, Baja California, Mexico: assessing multiple threats. Biodiversity and Conservation 2:62-69.

Oberbauer, T.A. 1987. Floristic analysis of vegetation communities on Isla de Cedros, Baja California, Mexico. Pages 115-131 in F.G. Hochberg, editor, Third California Islands Symposium: recent advances in research on the California islands. Santa Barbara Museum of Natural History, Santa Barbara, CA.

Oberbauer, T.A. 2002a. Analysis of vascular plant species diversity of the Pacific Coast islands of Alta and Baja California. Pages 201-211 in H.W. Chaney, K.L. Mitchel, and D.R. Browne, editors, Proceedings of the Fifth California Islands Symposium. Santa Barbara Museum of Natural History, Santa Barbara, CA.

Oberbauer, T.A. 2002b. Vegetation and flora of Islas Los Coronados, Baja California, México. Pages 212-223 in H.W. Chaney, K.L. Mitchel, and D.R. Browne, editors, Proceedings of the Fifth California Islands Symposium. Santa Barbara Museum of Natural History, Santa Barbara, CA.

o'Brien, B., J. Delgadillo-Rodríguez, S.A. Junak, T.A. Oberbauer, J.P. Rebman, H. Riemann, and S.E. VANDERPLANK. In press. The rare, endangered and endemic plants of the California Floristic Province Portion of Baja California, Mexico. Aliso.

Ratay, S.E., S.E. Vanderplank, and B.T. Wilder. 2014. Island specialists: shared flora of the Alta and Baja California Pacific Islands. Monographs of the Western North American Naturalist 7:161-220.

Rebman, J.P. 2006. The flora of Cedros Island, Mexico. San Diego Natural History Museum, San Diego, CA. http://bajaflora.org/Floras/CedrosIsland.htm

Rebman, J.P., J. Gibson, and K. Rich. 2016. Annotated checklist of the vascular plants of Baja California, Mexico. San Diego Natural History Museum, San Diego, CA. 352 pp.

Rebman, J.P., T.A. Oberbauer, and J.L. LeÓn de La LuZ. 2007. La flora de Isla Guadalupe y sus islotes adyacentes, Baja California, México. http://www2.ine.gob .mx/publicaciones/libros/477/cap5.html 
Rodríguez-Malagón, M.A., A. Aguirre-Muñoz, B. ROLDÁN-ClaRA, Y. BEDOLLA-GUZMÁN, R. GONZÁLEZGómez, F. Torres-García, ET AL. 2010. Introduced mouse eradication on San Benito Oeste Island, Mexico. Third pre-eradication report 2008-2010. Presented for consideration to the David and Lucile Packard Foundation, Conservation and Science Program. Grupo de Ecología y Conservación de Islas, A.C., Ensenada, BC, México.

Tershy, B.R., C.J. Donlan, B.S. Keitt, D.A. Croll, J.A. Sanchez, B. Wood, M.A. Hermosillo, G.R. HoWALD, AND N. BIAVASCHI. 1997. Island conservation in north-west Mexico: a conservation model integrating research, education, and exotic mammal eradication. Pages 293-300 in C.R. Veitch and M.N. Clout, editors, Turning the tide: the eradication of invasive species. IUCN SSC Invasive Species Specialist Group. IUCN, Gland, Switzerland, and Cambridge, United Kingdom.
Vanderplank, S., AND S. Mata. 2010. Threats to an extreme endemic: Chenopodium flabellifolium (Amaranthaceae) on Isla San Martín. Crossosoma 36(2): $50-56$.

Vanderplank, S., A. Peralta Garcia, J. Valdez VillaviCENCIO, AND C.A. DE LA Rosa. 2017. Plantas y Animales Unicos de las islas de Baja California [Unique Plants and Animals of the Baja California Islands]. Botanical Research Institute of Texas, Fort Worth, TX. 136 pp.

Wallace, G.D. 1985. Vascular plants of the Channel Islands of southern California and Guadalupe Island, Baja California, México. Contributions in Science 365, Natural History Museum of Los Angeles County.

Received 7 March 2017 Revised 28 February 2018

Accepted 14 March 2018

Published online 13 December 2018 


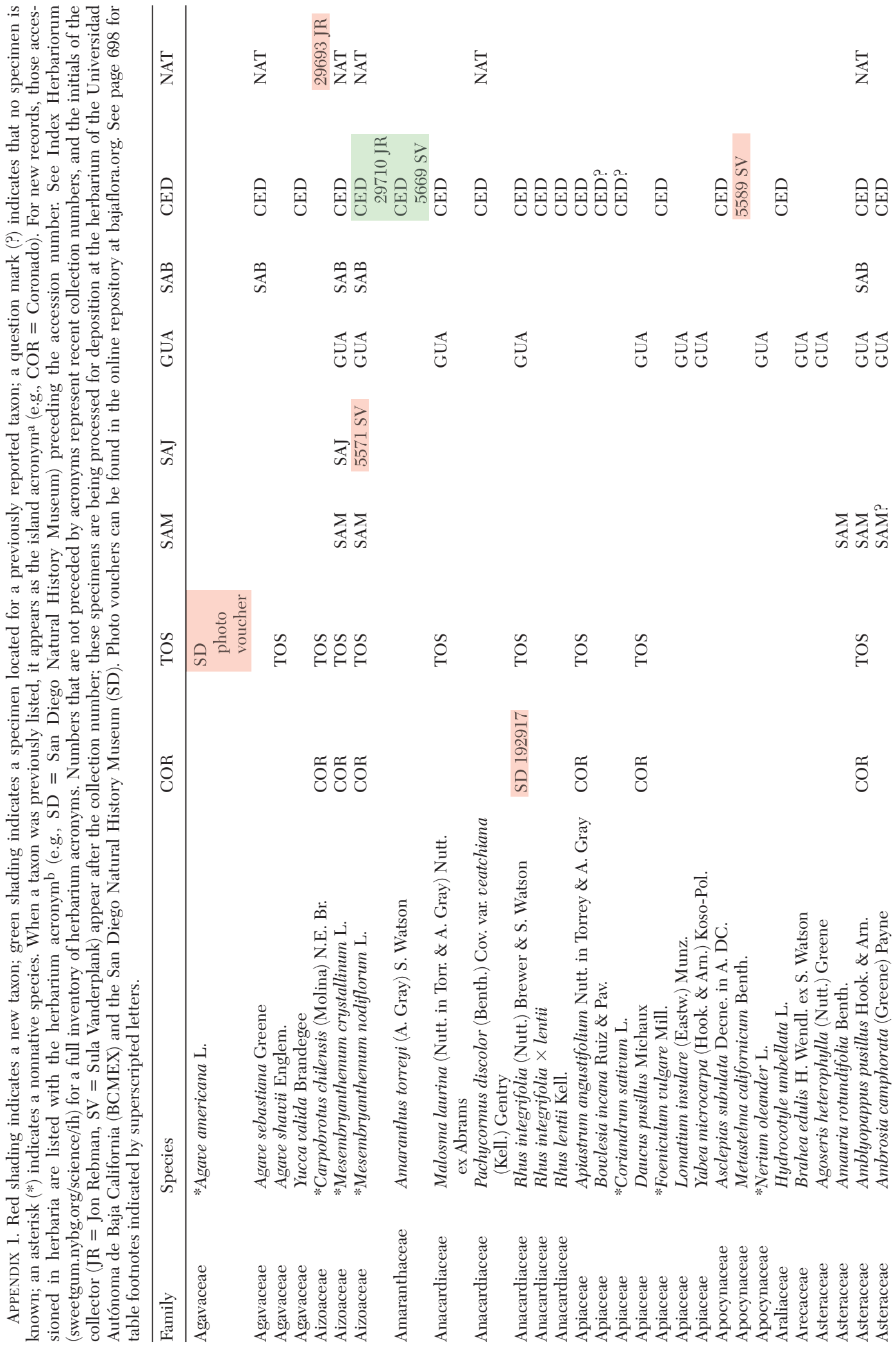


Vanderplank et al. • Baja California Plant Checklists

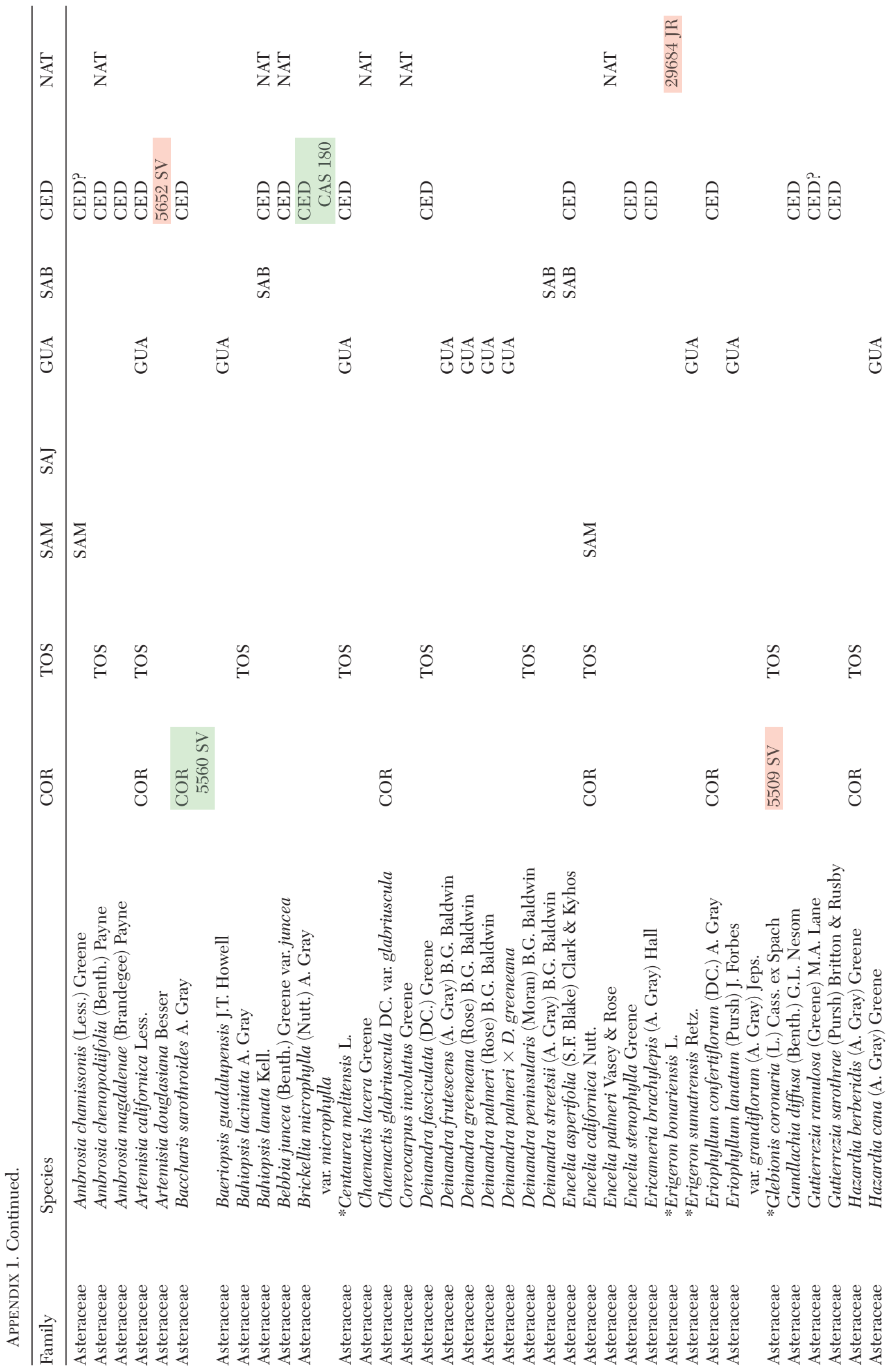




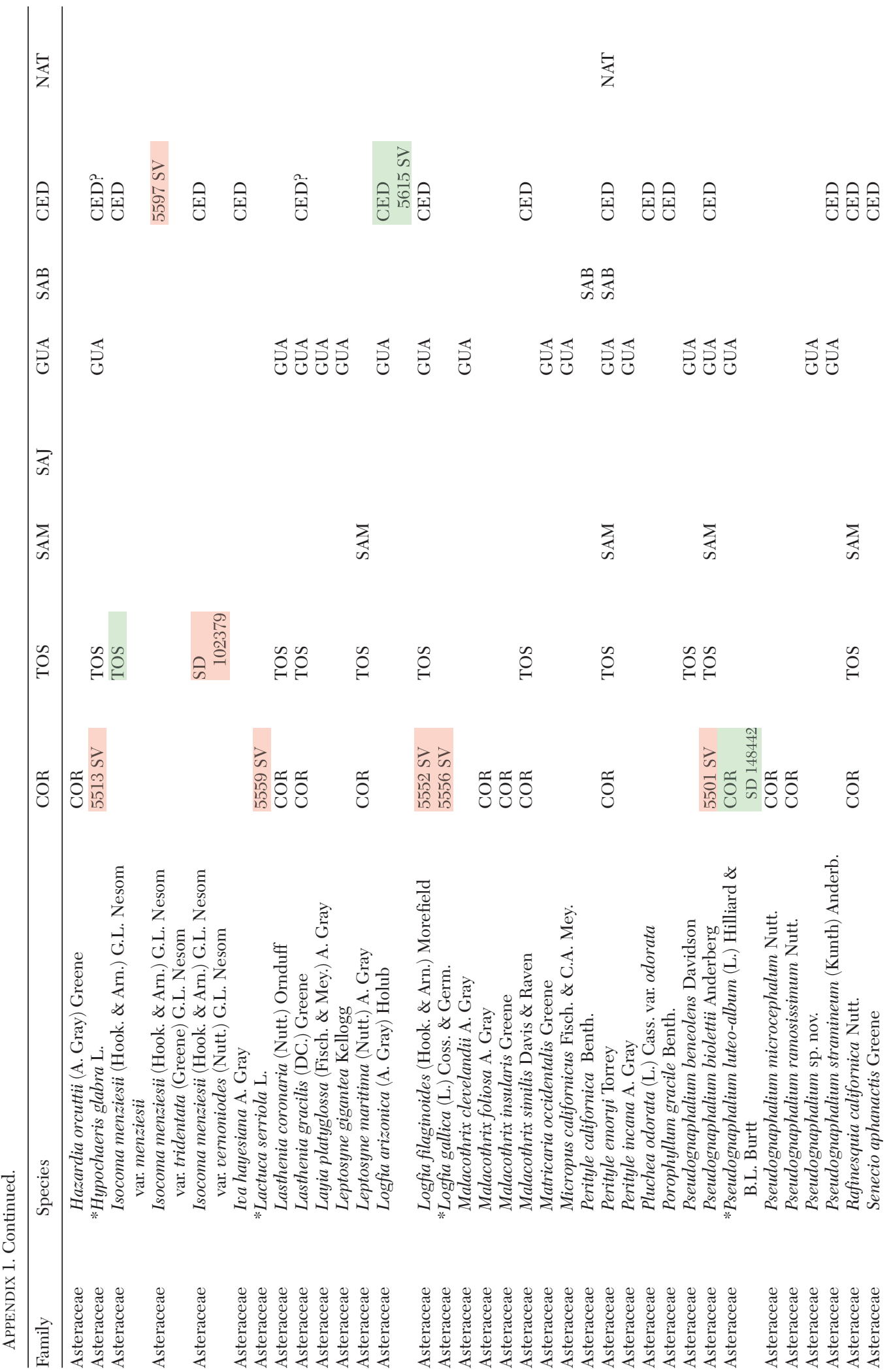


Vanderplank et al. - Baja California Plant Checklists

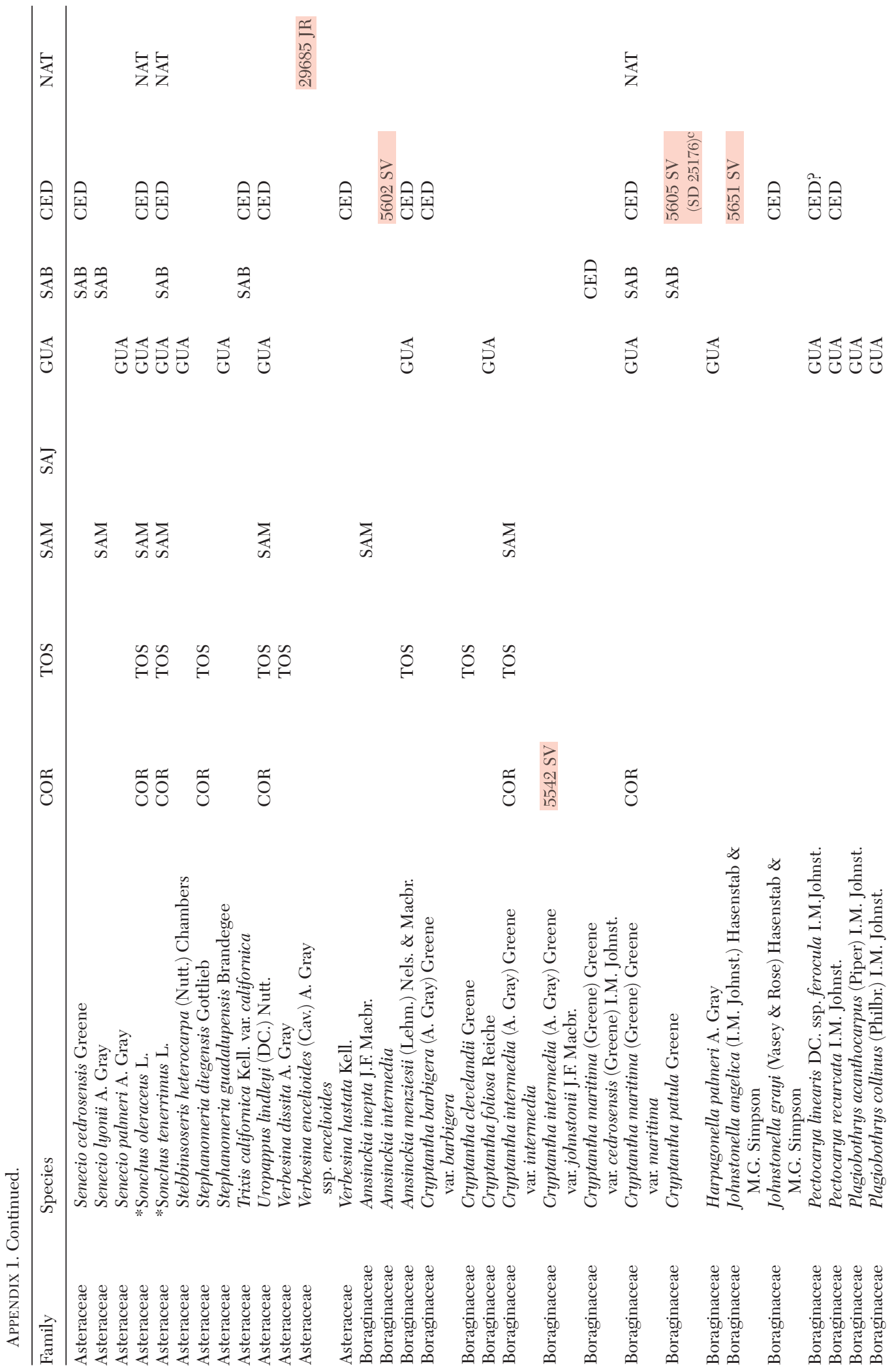




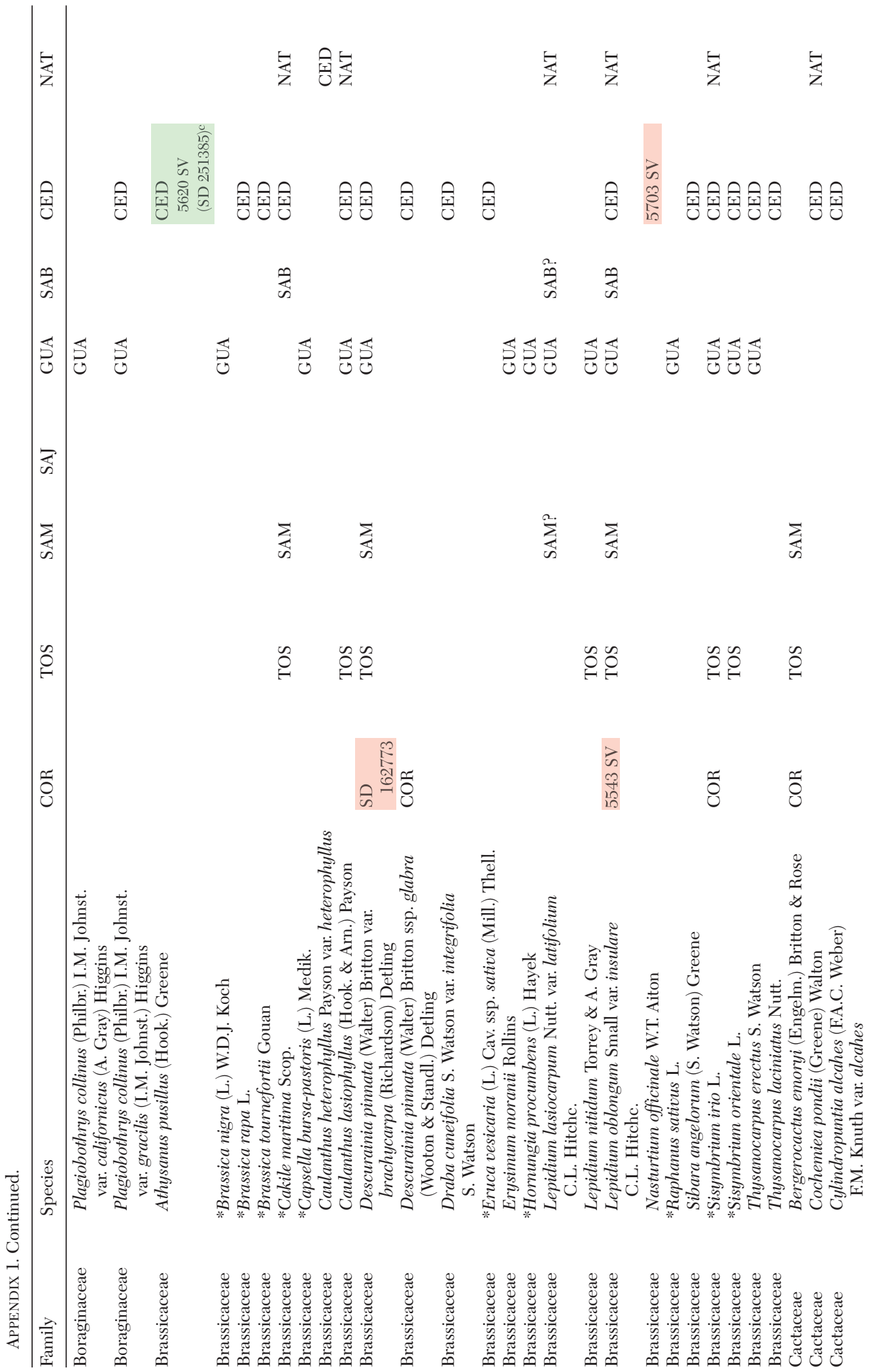


Vanderplank et al. • Baja California Plant Checklists

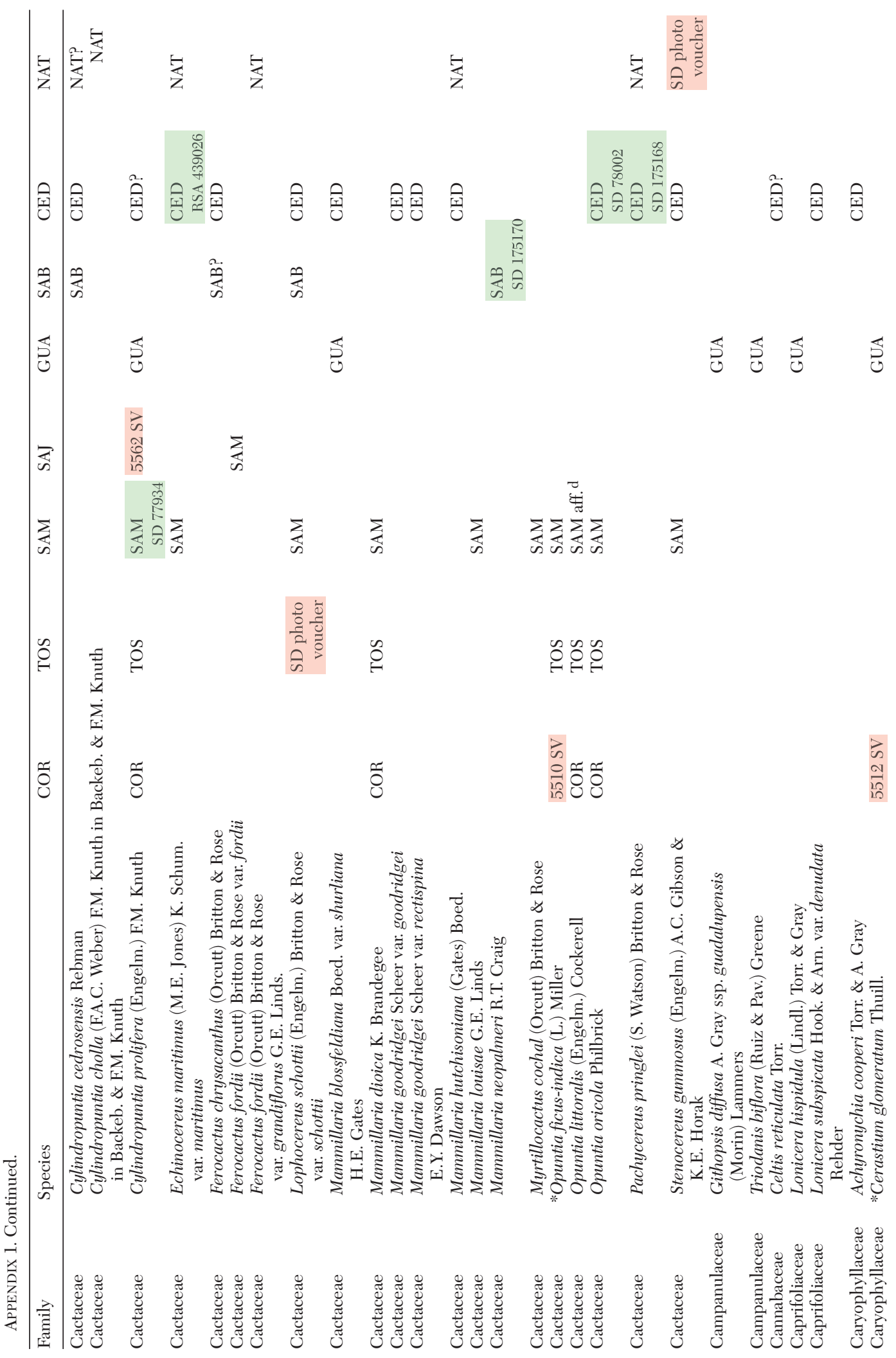




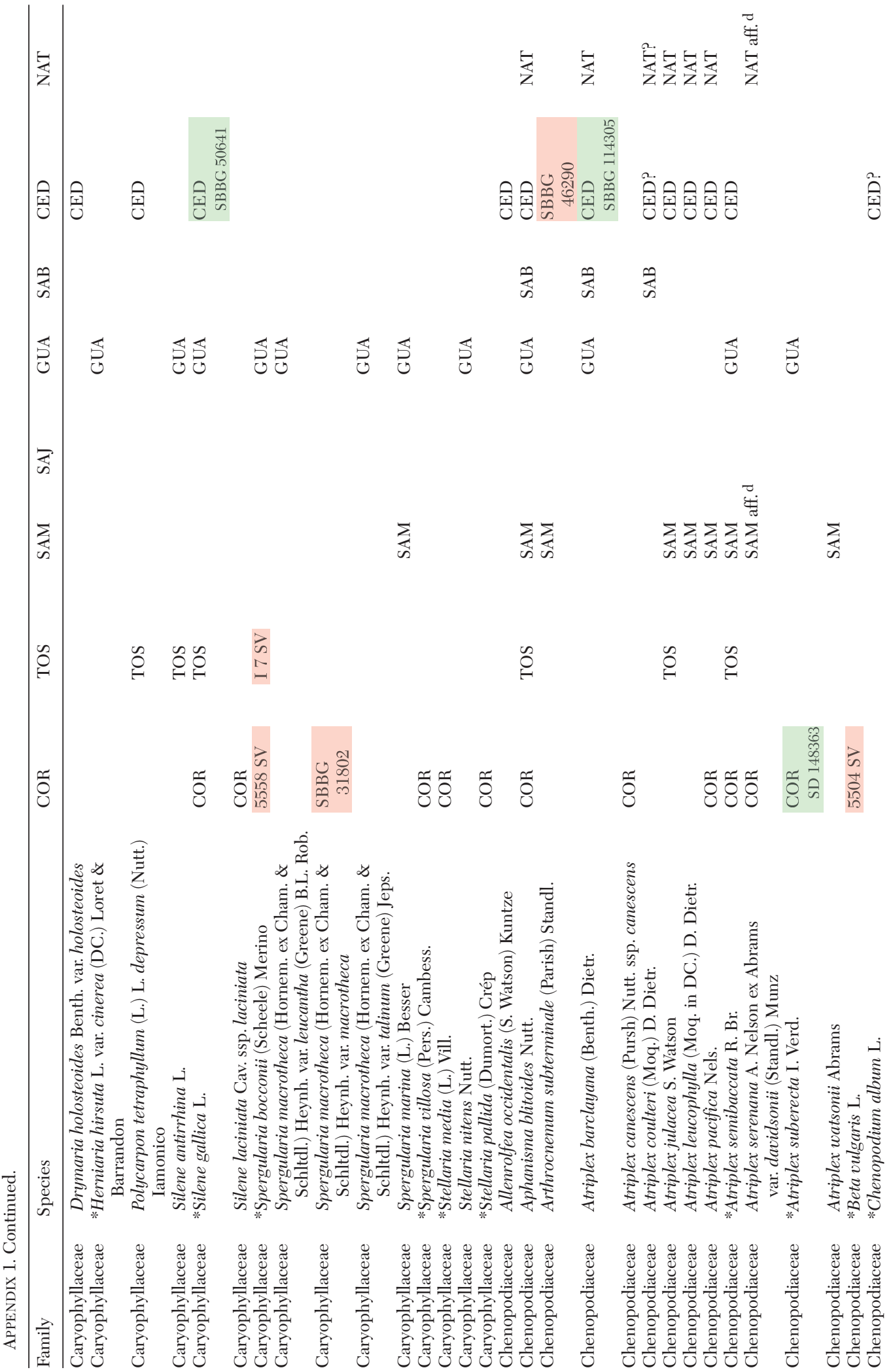


Vanderplank et al. - Baja California Plant Checklists

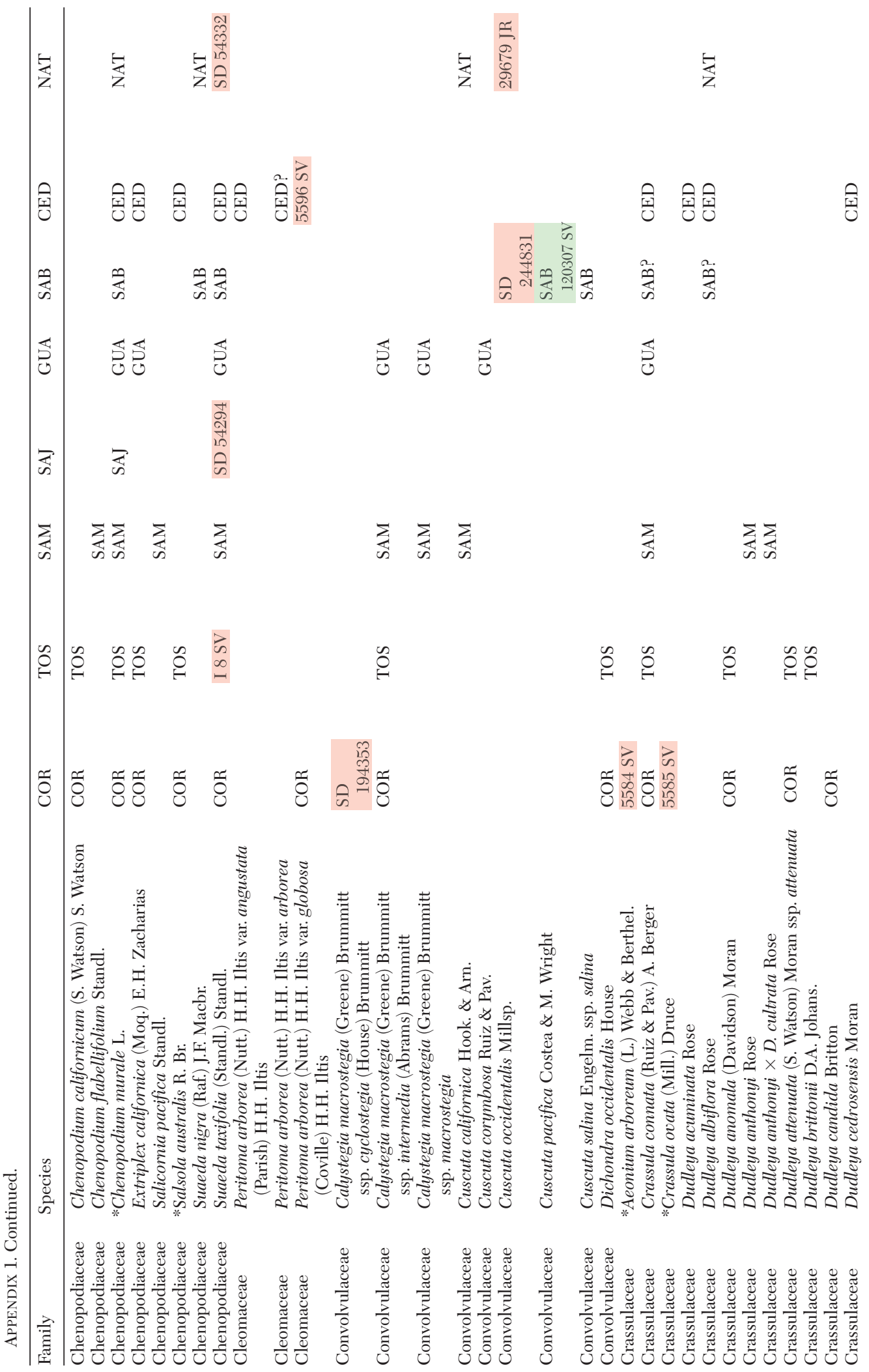




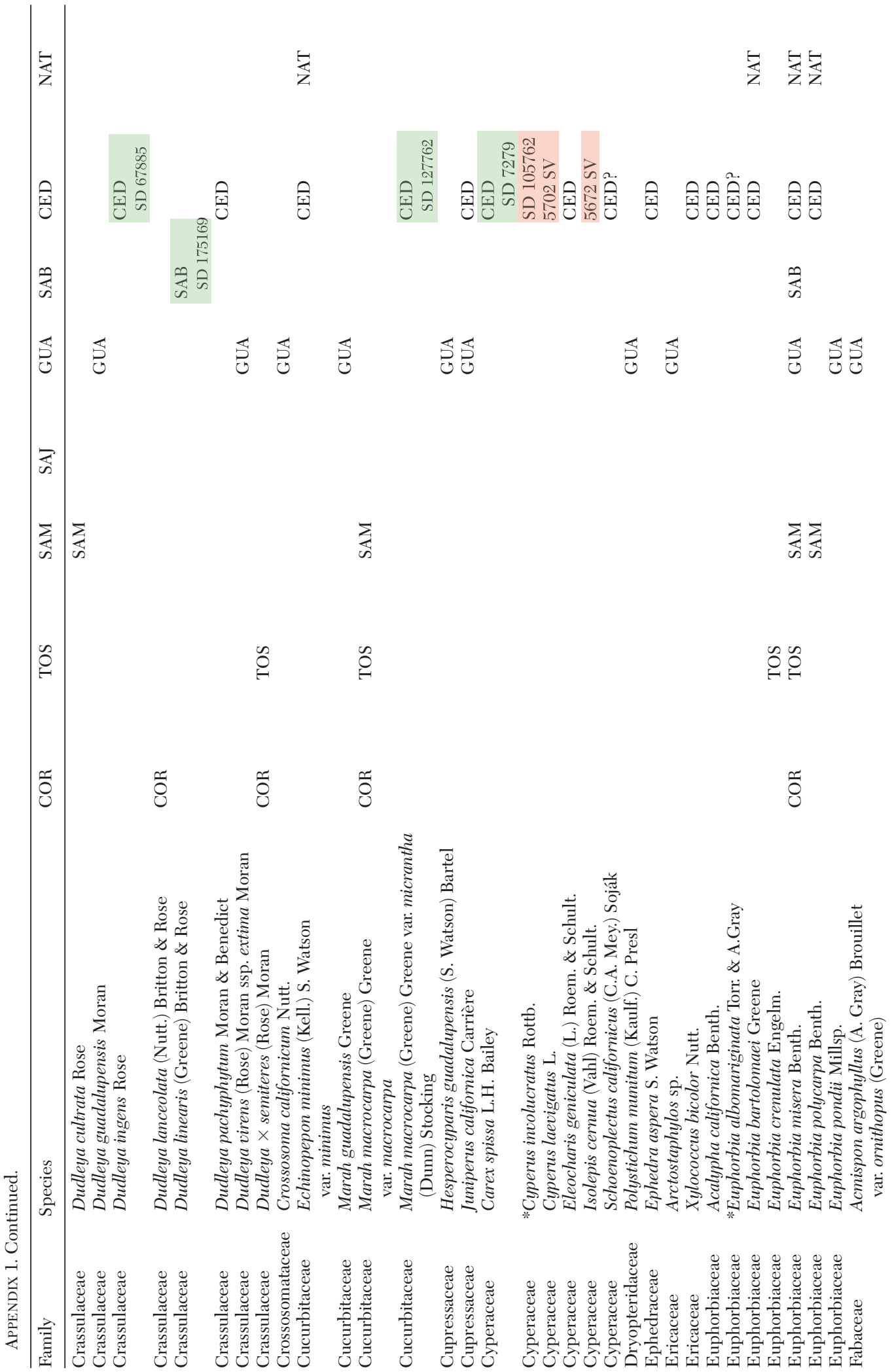


Vanderplank et al. • Baja California Plant Checklists

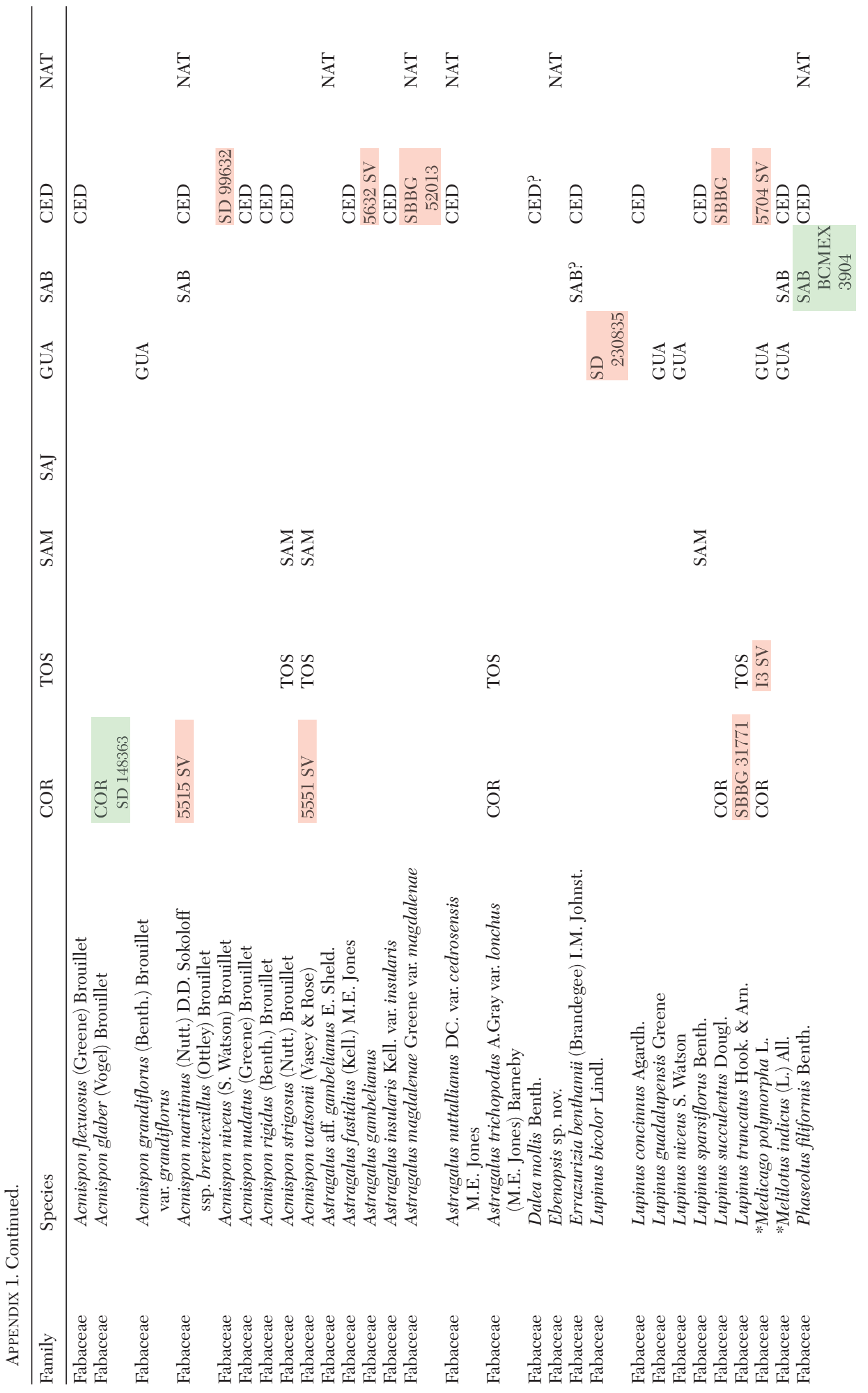




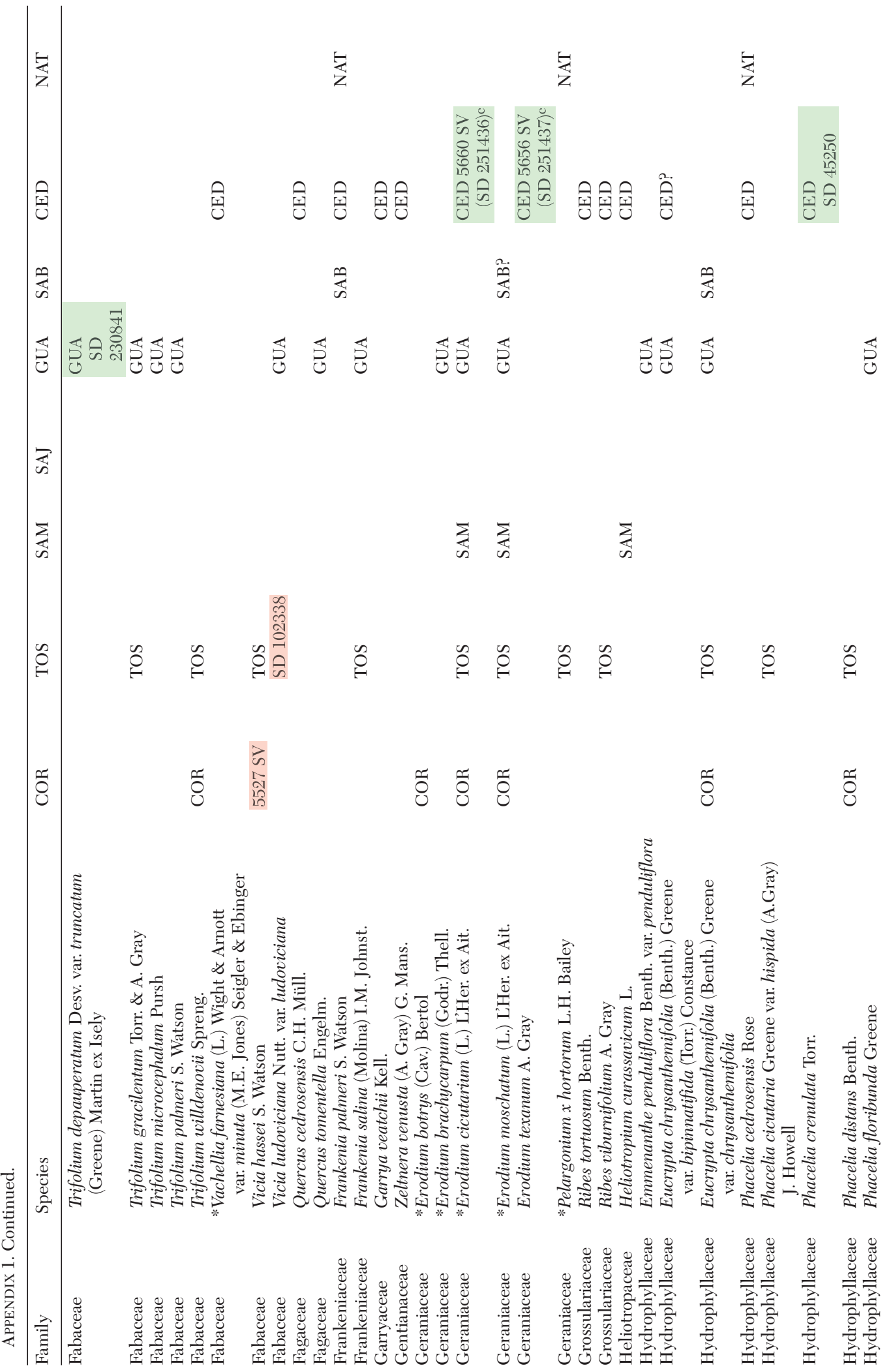


Vanderplank et al. • Baja California Plant Checklists

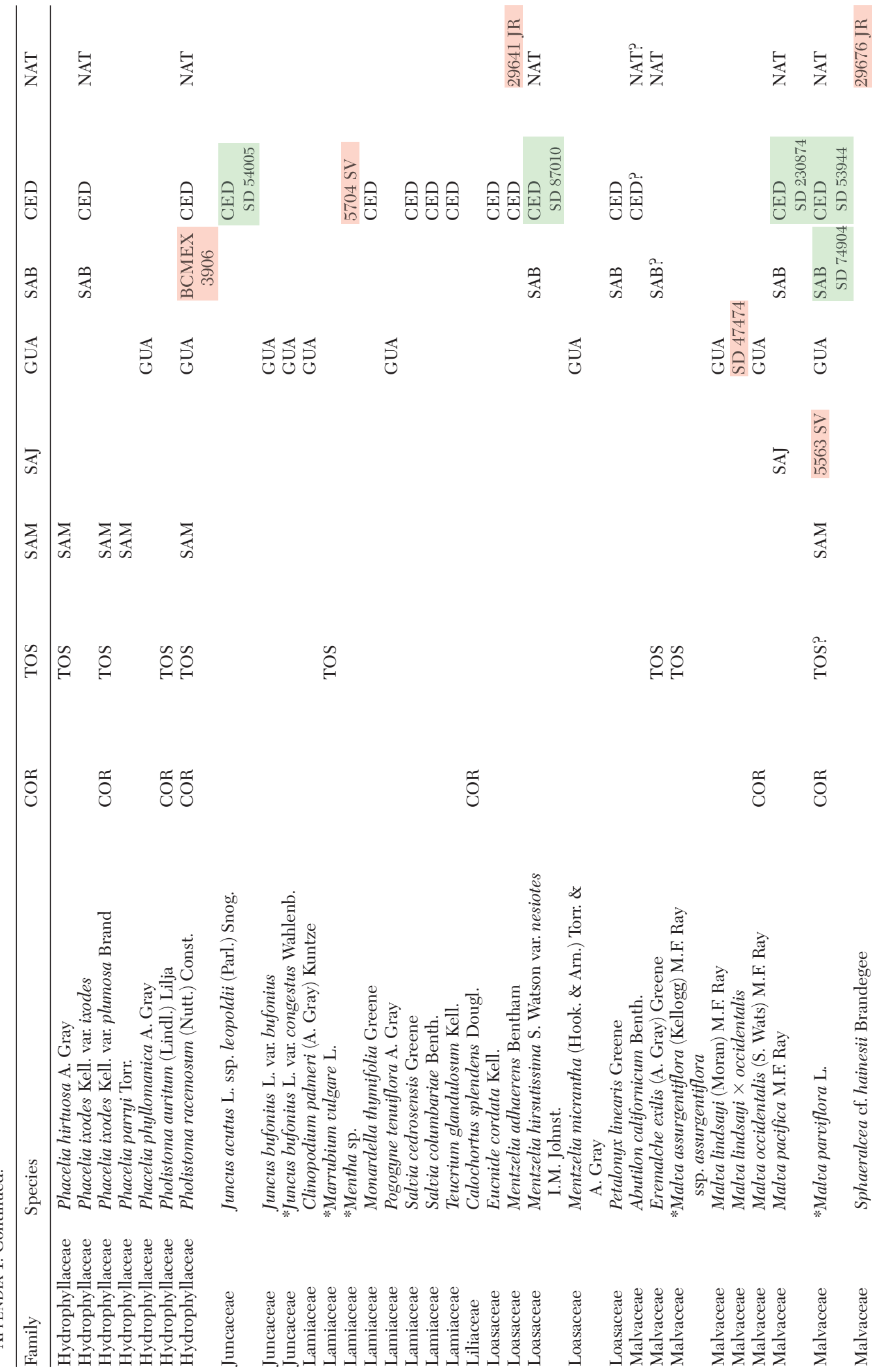




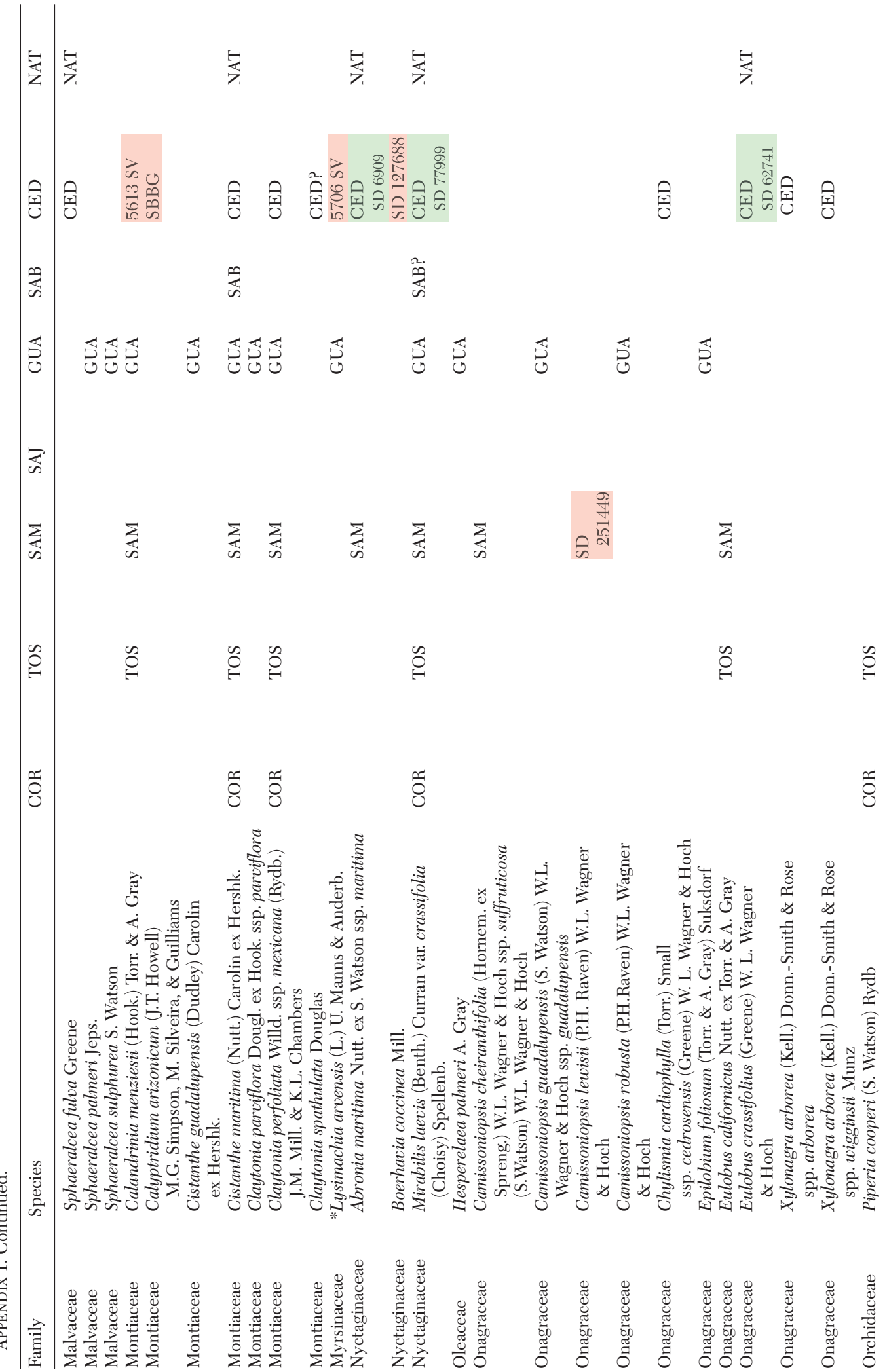


Vanderplank et al. Baja California Plant Checklists

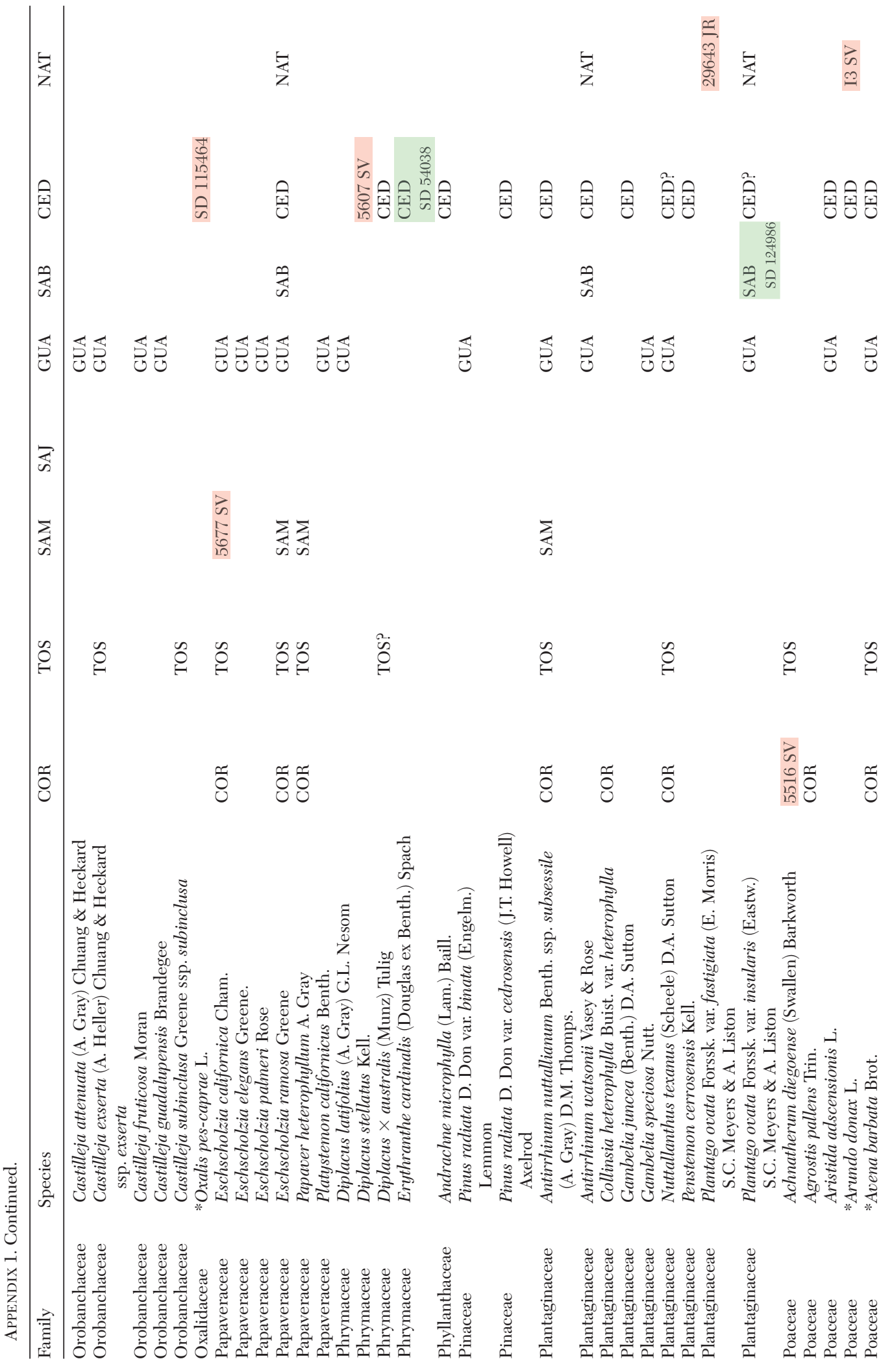




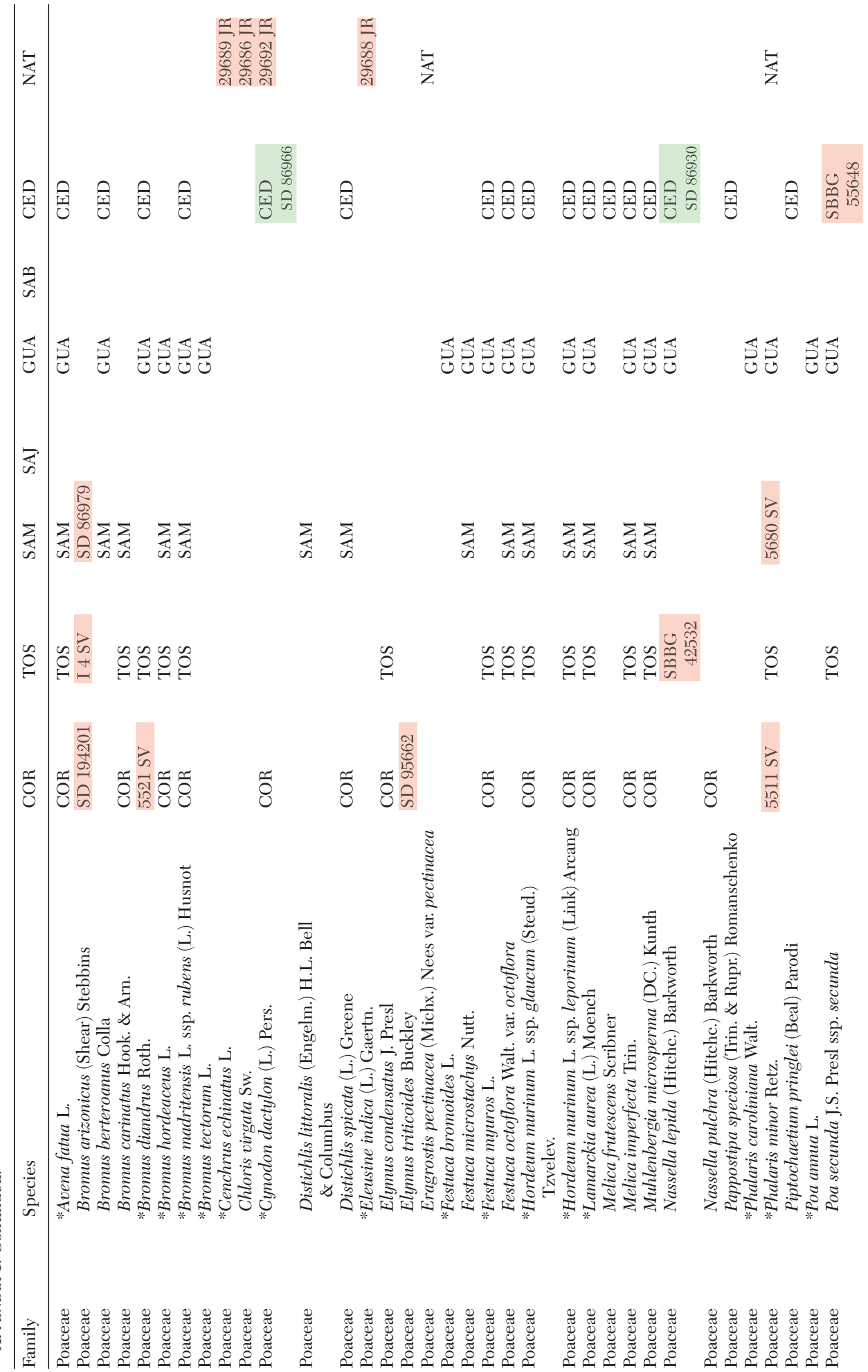


Vanderplank et al. • Baja California Plant Checklists

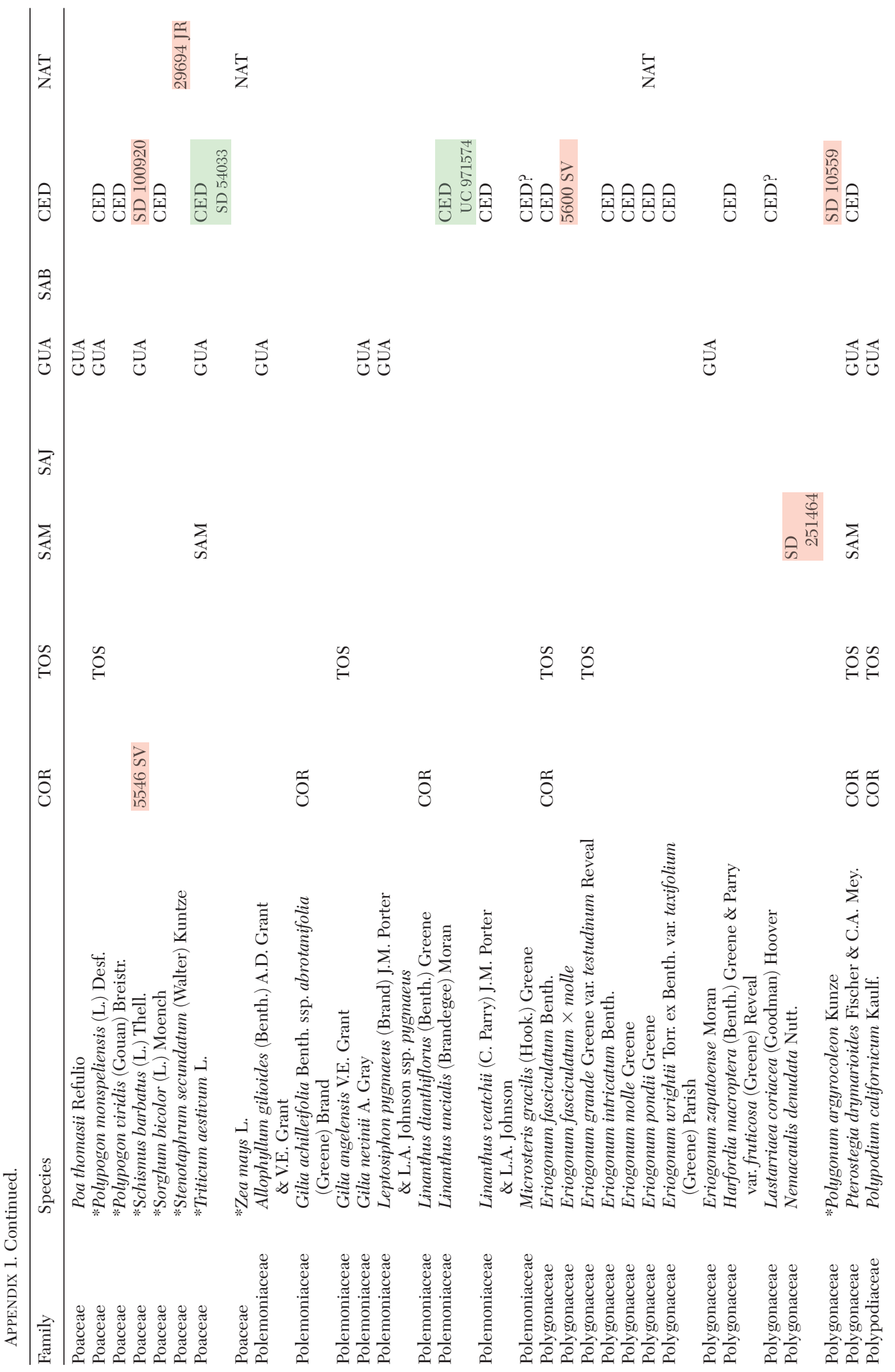




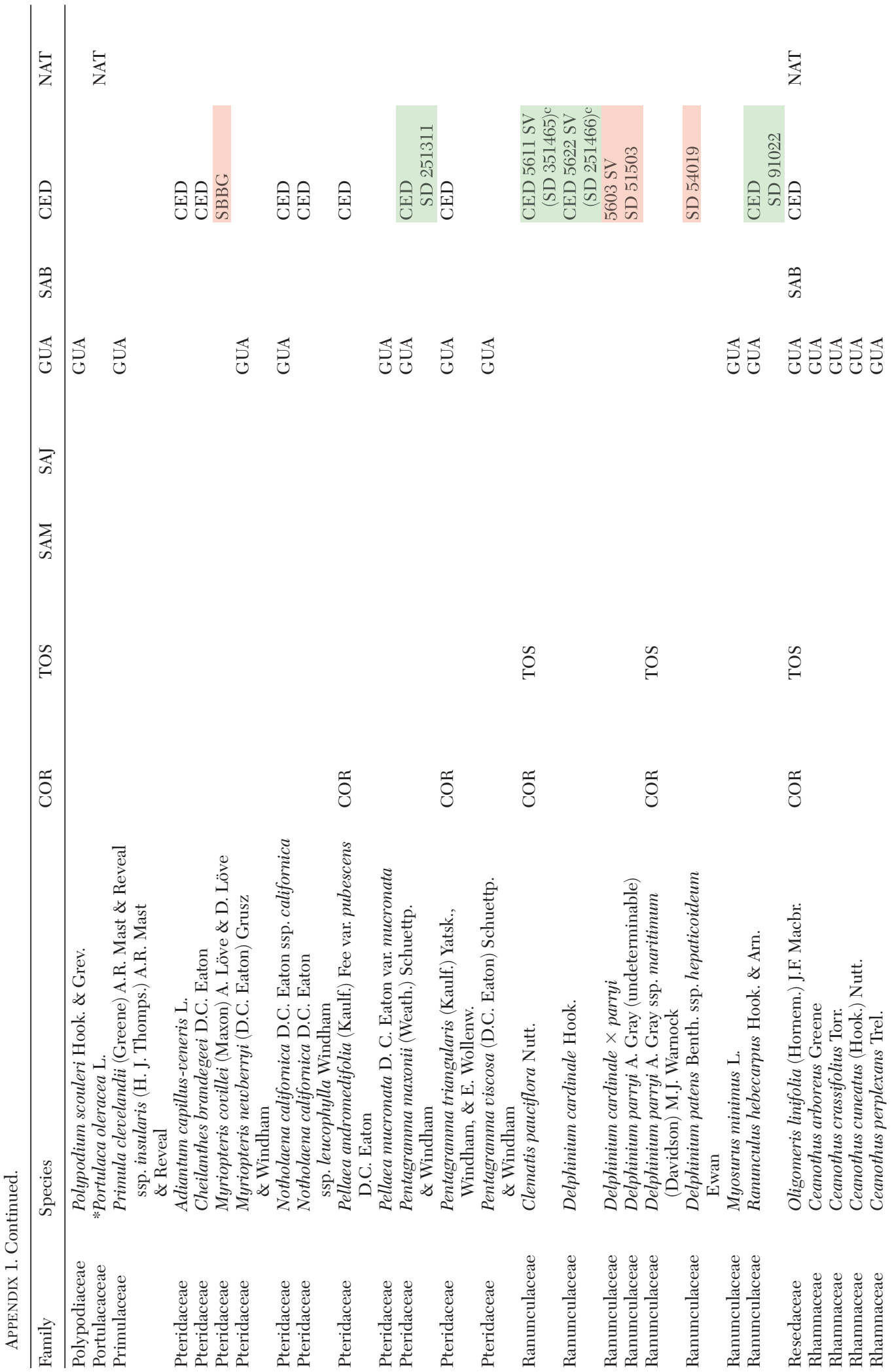


Vanderplank et al. • Baja California Plant Checklists

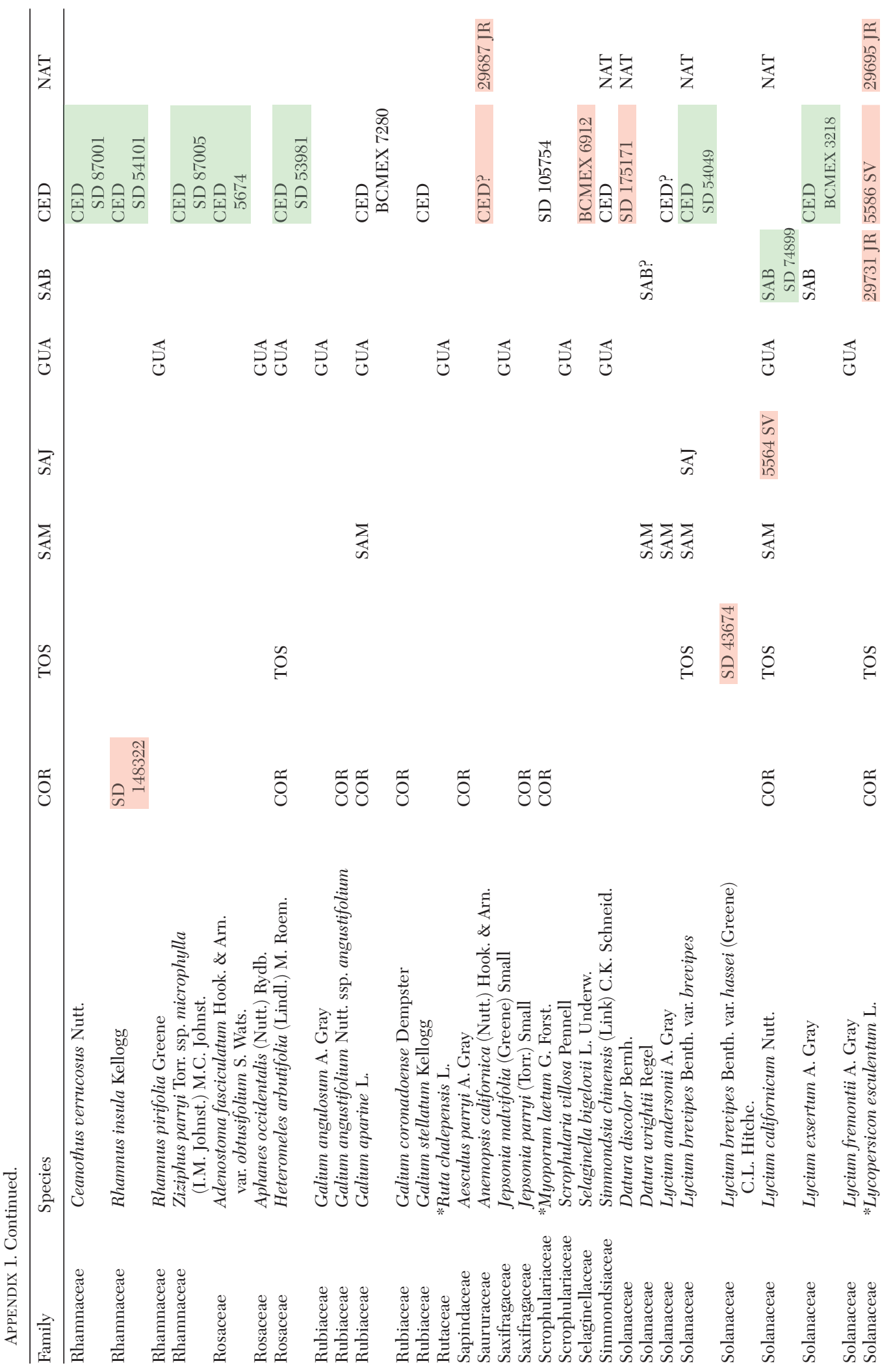




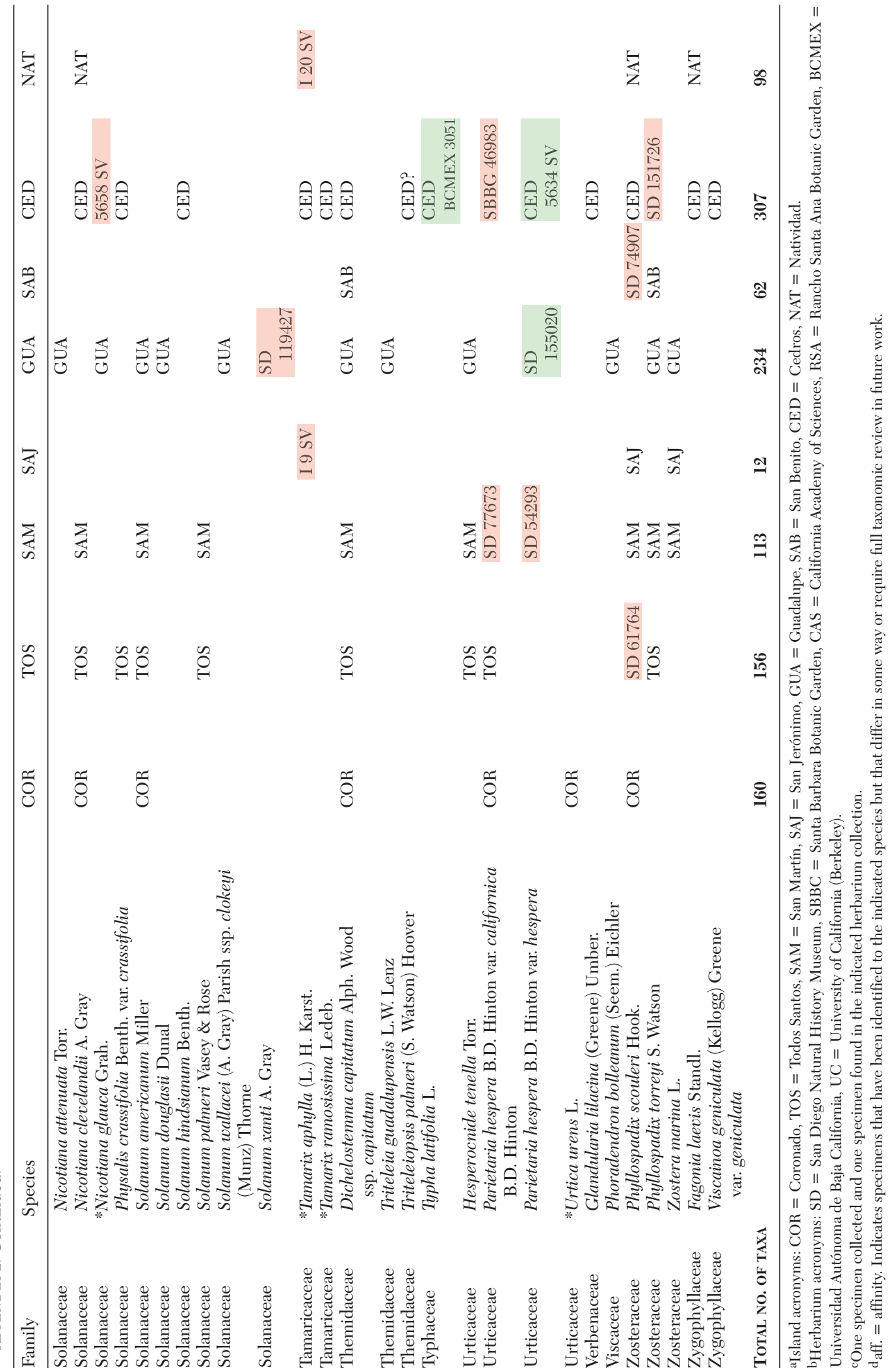

